\title{
Gelişmekte Olan Piyasa Ekonomilerinin İhracat Performansının Bulanık AHP ve TOPSIS Yöntemi ile Değerlendirilmesi*
}

\author{
Evaluation of the Export Performance of Emerging Market \\ Economies with Fuzzy AHP and TOPSIS Method
}

\section{Prof. Dr. Nihat Işık - Arş. Gör. Özgür Engeloğlu - Arş. Gör. Serhat Karaoğlan}

\author{
Başvuru Tarihi: 21.11.2016
}

Kabul Tarihi: 04.08.2017

\section{Öz}

Bu çalşmada, yükselen piyasa ekonomisi ülkelerinin 2013 yil ihracat performansı bulanik AHP ve TOPSIS yöntemleri ile ölçülmüs ve analize dâhil olan 22 ülke performanslarına göre sıralanmıștır. AHP yöntemi ile uzman görüşleri alınarak yapilan değerlendirme sonucunda belirlenen ağırliklara göre, en önemli gösterge olarak yüksek teknoloji ürünlerinin ihracatı (HTECH) ön plana çıkmıştır. TOPSIS yöntemi kullanılarak yapılan analiz sonucunda, HTECH göstergesi en yüksek ülke olan Filipinler belirlenen ağırliklarm da etkisiyle 2013 yıl itibarıla ihracat performansi en iyi ülke olmuştur. Yine HTECH göstergesi en yüksek 6 ülke aynı zamanda ihracat performansı en iyi 6 ülke olarak sıralanmıştır.

Çalışmada Türkiye’nin ise 22 ülke arasında 17. sırada yer aldiğ̀ gözlemlenmektedir. 7 göstergenin 6’sinda ilk 16 ülke arasında yer alan Türkiye'nin siralamada bu kadar gerilerde kalmasının başlıca sebebi, en önemli gösterge olarak belirlenen HTECH göstergesinde 20. strada yer almasıdır. Buna göre, Türkiye'nin ihracat performansinin artmasinda HTECH ürünlerinin ihracattaki payın artırmaya dönük politikalar uygulanması oldukça önemli olacaktır.

Anahtar Kelimeler: İhracat, Ekonomik Büyüme, Bulanik AHP, TOPSIS

\begin{abstract}
In this study, export performance of emerging market economies were measured with AHP and TOPSIS method, and 22 countries were ranked according to their performance. According to the evaluation to AHP method with experts' opinion, high-technology exports (HTECH) was determined the most important indicator. As a result of TOPSIS analysis; Philippines, which has the highest value on HTECH indicator, has been the best country in terms of export performance as of 2013, with the help of determined weightings. Moreover, the countries which have the top six HTECH value, also have the top six export performance.
\end{abstract}

It is observed in this study; Turkey ranked 17th among the 22 countries. Although Turkey has one of the best sixteen values on six of seven indicators, is placed near the bottom of the export performance ranking. The main reason of this situation; Turkey was the 20th countries at HTECH. It is important to implement a policy about increase the share of HTECH products on total export, for increasing Turkey's export performance.

Keywords: Export, Economic Growth, Fuzzy AHP, TOPSIS

Prof. Dr. Nihat Işık, Kırıkkale Üniversitesi İİBF, nihatis@hotmail.com Arş. Gör. Özgür Engeloğlu, Kırıkkale Üniversitesi İ̇̈B, engelogluo@gmail.com

Arş. Gör. Serhat Karaoğlan, Kırıkkale Üniversitesi İ̈BF, serhat@karaoglan.net

* Bu makale 17. Uluslararası Ekonometri, İstatistik ve Yöneylem Araştırması Sempozyumu’nda sözlü olarak sunulmuş ve özeti bildiri kitapçı̆̆ında basılmıştır. 


\section{Giriş}

Ülke refahı üzerindeki pozitif etkisi dikkate alınd1ğında ekonomik büyümenin arttırılması tüm ülkeler açısından temel önceliklerden biridir. Diğer taraftan büyümenin ihracat temelli mi, yoksa ithalata dayalı mı olduğu da oldukça önemlidir. İhracat; hem ülkenin elde edeceği döviz gelirinin artmasına, hem ihraç ürünlerine dönük talep artışının istihdamı artıracak olmasına, hem de ülkenin dünya ile bütünleşmesine katkı gibi boyutları nedeniyle ülkeler açısından çok dikkatle izlenen bir göstergedir.

Çalışmanın araştırma örneklemini Yükselen Piyasa Ekonomileri (YPE) kapsamındaki geleceği en parlak gözüken ülkeler içermektedir. YPE’nin belirlendiği pek çok liste olmakla birlikte (BRICS + Next Eleven, FTSE, MSCI, S\&P, Dow Jones vb.), bu çalışmada IMF tanımlamasında belirlenmiş ülkeler dikkate alınacaktır. IMF tanımlamasına göre $23 \mathrm{YPE}^{1}$ ülkesi bulunmaktadır.

Çalışmanın temel motivasyonu, hem ilgili ülkelerin ihracat performansı açısından birbirlerine karşı mevcut durumlarını değerlendirmek, hem de ihracat performansı en yüksek ülkeleri belirlemektedir. Bu kapsamda çalışmada, verilerine ulaşılamayan Bangladeş hariç 22 YPE ülkensinin ihracat performansı seçilmiş göstergeler yardımıyla ölçülecektir. Veriler Dünya Bankasinın World Development Indicator (WDI) veri tabanından temin edilen 2013 yllı rakamlarıdır. İhracat performansının ölçümü için kullanılan 7 gösterge ise; ihracat değeri endeksi $(2000=100)$, konteynır başına ihracat maliyeti (\$), ihracat için gereken doküman sayısı, yüksek gelirli ülkelere yapılan mal ihracatı (toplam mal ihracatı içindeki yüzdesi), mal ve hizmet ihracatı (GDP içindeki yüzdesi), yüksek teknoloji ihracatı (sanayi ürünleri ihracatı içindeki yüzdesi) ve sanayi ürünleri ihracatıdır (toplam mal ihracat içindeki yüzdesi).

Çalışmada öncelikle ihracat ve ekonomik büyüme ilişkisi üzerinde durularak bu konuda yapılmış uygulamalı çalışmalardan bahsedilecektir. İkinci kısımda performansı ölçmek için kullanılacak olan bulanık AHP (Analytic Hierarchy Process) ve TOPSIS (Tech-

1 Bu ülkeler; Arjantin, Bangladeş, Brezilya, Bulgaristan, Şili, Çin, Kolombiya, Macaristan, Hindistan, Endonezya, Malezya, Meksika, Pakistan, Peru, Filipinler, Polonya, Romanya, Rusya, Güney Afrika, Tayland, Türkiye, Ukrayna ve Venezueladır (IMF, 2015). nique for Order Preferance by Similarity to Ideal Solution) yöntemleri ve bu yönteme ilişkin literatür üzerinde durulacaktır. Uygulamayı içeren üçüncü kısmın ardından çalışma, uygulama sonuçlarının değerlendirileceği sonuç ve değerlendirme ile tamamlanacaktır.

\section{İhracat-Ekonomik Büyüme İlişkisi}

Ekonomik büyüme en basit haliyle milli gelirin bir yıldan diğerine artışı olarak tanımlanabilir. Açık ekonomi makro iktisadında milli gelir özdeşliğinin; tüketim (C), yatırım (I), kamu harcamaları $(\mathrm{G})$ ve net ihracat (X-M) değişkenlerinden oluştuğu dikkate alınırsa, ihracat, milli gelire ve dolayısıyla ekonomik büyümeye pozitif katkısı olan, aynı zamanda ülkenin uyguladığı politikalar ile de doğrudan ilişkili olan önemli bir değişkendir.

Ekonomik büyüme sonucunda kişi başına düşen gelirin artışı ile birlikte toplumun yaşam standardının ve refahının da benzer şekilde artması beklenir (Saleem ve Sial, 2015: 18). İnsanların yaşam kalitesini artıracağı konusunda yarattığı beklenti nedeniyle büyüme olgusu, incelenmek için oldukça ilgi çeken temalardan biri olagelmiştir. Büyümeye yol açan durumlar göz önüne alındığında ise, uluslararası ticaretin ülke ekonomisi açısından önemi büyüktür. Bu bağlamda, büyüme ile uluslararası ticaret arasındaki ilişkide öne çıkan üç teori vardır. Bunlar; ihracata dayalı büyüme hipotezi, ilkinin tersi olarak büyümenin başı çektiği büyümeye dayalı ihracat hipotezi ve ithalatı ekonominin motoru olarak gören ithalata dayalı büyüme hipotezidir (Kristjanpoller ve Olson, 2014, s. 6).

İhracatın ekonomik büyümeye yönelik birden fazla etkisi mevcuttur. İhracatla birlikte uluslararası piyasalara giriş; rekabeti artırır, kaynak tahsisini geliştirir, ihracat dışı sektörlere yeni teknolojilerin yayılmasına (spillover) imkân verir, ekonomideki verimliliği artırır ve etkili bir fiyat mekanizmasının oluşmasına katkı sağlar. Yerli mallara olan dış talebin artmasının ülke içinde yeni yatırımları uyarması, dolayısıyla, belirli sektörlere yapılan yatırımların artmasına neden olması da ihracatın ortaya çıkardığı önemli etkilerdendir. İhracat, uzmanlaşma konusunda yaratacağ etkinin yanı sıra iç pazarı dar olan ekonomiler için ekonomik ölçekte üretim yapma imkânı da sağlamaktadır. Yine ihracatla birlikte döviz gelirlerinin 
artması, dış ödemelerdeki döviz baskısını azaltacak, böylece yerli üretimi artırmada önemli rol oynayabilecek çeşitli girdiler ve sermaye mallarının ithalatının artması da mümkün olacaktır (Şimşek, 2003, s. 43-44).

Literatürde, gerek ihracatın diğer değişkenlere olan etkisine, gerekse de ihracatı etkileyen değişkenlere yönelik birçok çalışma mevcuttur. İhracatın etkilediği ve etkilendiği değişkenlerden en çok incelenen değişken ise ekonomik büyümedir. Büyük oranda nedensellik testleri kullanılarak yapılan çalışmaların sonuçları incelendiğinde ise üç farklı bulguya rastlanıldığı gözlemlenmektedir. Bunlardan ilki, ihracatın ekonomik büyümeyi etkilediği $(X \rightarrow Y)$, ikincisi ekonomik büyümenin ihracatı tetiklediği $(X \leftarrow Y)$, üçüncüsü ise hem ihracatın ekonomik büyümeyi hem de ekonomik büyümenin ihracatı etkilediği $(\mathrm{X} \leftrightarrow \mathrm{Y})$ bulgusudur.

Tablo 1. İhracat ve Ekonomik Büyüme Üzerine Yapılmış Uygulamalı Çalışmaların Özeti

\begin{tabular}{cccc}
\hline Yazar & Ülkeler & Dönem & Sonuç \\
\hline Michaely (1977) & 45 ülke & $1950-1973$ & $\mathrm{X} \rightarrow \mathrm{Y}$ \\
Balassa (1978) & 11 gelişmiş ülke & $1960-1973$ & $\mathrm{X} \rightarrow \mathrm{Y}$ \\
Tyler (1981) & 55 Orta gelirli ülke & $1960-1977$ & $\mathrm{X} \rightarrow \mathrm{Y}$ \\
Feder (1983) & Yarı sanayileşmiş/az gelişmiş bir grup ülke & $1964-1973$ & $\mathrm{X} \rightarrow \mathrm{Y}$ \\
Kavoussi (1984) & 73 gelişmekte olan ülke & $1960-1978$ & $\mathrm{X} \rightarrow \mathrm{Y}$ \\
Ram (1987) & 88 gelişmekte olan ülke & $1960-1982$ & $\mathrm{X} \rightarrow \mathrm{Y}$ \\
Kunst ve Marin (1989) & Avusturya & $1965-1985$ & $\mathrm{X} \leftarrow \mathrm{Y}$ \\
Marin (1992) & gelişmiş ülke & $1960-1987$ & $\mathrm{X} \rightarrow \mathrm{Y}$ \\
Bahmani-Oskooee ve Alse (1993) & 9ülke & $1973-1988$ & $\mathrm{X} \leftrightarrow \mathrm{Y}$ \\
Sengupta ve Espana (1994) & Kore & $1967-1986$ & $\mathrm{X} \rightarrow \mathrm{Y}$ \\
Kwan ve Kwok (1995) & Çin & $1952-1985$ & $\mathrm{X} \rightarrow \mathrm{Y}$ \\
Doraisami (1996) & Malezya & $1963-1993$ & $\mathrm{X} \leftrightarrow \mathrm{Y}$ \\
Frankel ve Romer (1996) & 150 ülke & 1985 & $\mathrm{X} \rightarrow \mathrm{Y}$ \\
Henrıques ve Sadorsky (1996) & Kanada & $1870-1991$ & $\mathrm{X} \leftarrow \mathrm{Y}$ \\
Thornton (1996) & Meksika & $1895-1992$ & $\mathrm{X} \rightarrow \mathrm{Y}$ \\
Al-Yousif (1999) & Malezya & $1955-1996$ & $\mathrm{X} \rightarrow \mathrm{Y}$ \\
Ekanayake (1999) & 59 ülke & $1960-1992$ & $\mathrm{X} \rightarrow \mathrm{Y}$ \\
Awokuse (2003) & Kanada & $1960-1997$ & $\mathrm{X} \leftrightarrow \mathrm{Y}$ \\
Bahmani-Oskooee ve Niroomand (1999) & & $1961-2000$ & $\mathrm{X} \rightarrow \mathrm{Y}$ \\
\hline
\end{tabular}

Tablo 1, literatürde ihracat ve ekonomik büyüme arasındaki ilişkiye yönelik yapılmış olan uygulamalı çalışmaların sonuçlarını özetlemektedir. Tablodan da görülebileceği gibi, yapılan çalışmalar sonucunda ağırlıklı olarak ihracata dayalı büyüme hipotezini destekleyen bulgular ortaya çıkmış olup, kısmen de diğer iki hipotezi destekleyen sonuçlar ortaya çıkmıştır. Dikkat çeken bir başka husus ise, ekonomik büyümenin ihracatı tetiklediği hipotezi $(X \leftarrow Y)$ sadece iki ülke (Avusturya ve Kanada) için yapılan çalışmalarda desteklenmiştir.

Ülkelerin gösterdiği ihracat performanslarının kendi ekonomileri için son derece önemli olduğu gerçeği, aynı zamanda ülkelerin ihracat performansının ölçülmesi ve değerlendirilmesi yönünde çalışmalar yapılmasını da önemli kılmıştır. Bu kapsamda bu çalışmada, literatürde ülkeler ölçeğinde ihracat ile ilgili yapılmış çalışmalardan farklı olarak, ihracatın etkilediği ya da ihracattan etkilenen faktörler değil, ülkelerin gösterdikleri ihracat performansları çeşitli ihracat göstergeleri aracılığıyla ölçülmüştür. Çalışmada örneklem olarak YPE sınıfına dâhil olan ülkeler seçilmiştir. Analiz sonucunda, gelişmekte olan piyasa ekonomileri için son derece önemli bir faktör olan ihracata yönelik gösterilen performansın söz konusu ülkeler açısından resminin ortaya çıkarılması ve çıkan sonuca yönelik değerlendirmelerin yapılması planlanmaktadır.

Performans ölçümünde literatürde sıklıkla kullanılan TOPSIS yöntemi genellikle mikro ölçekte ve firmalar bazında performans ölçmek için kullanılmaktadır. Çeşitli kriterler (göstergeler) kullanılarak yapılan analiz sonucunda ortaya çıkan performans puanları ile alternatifler en iyi performans gösterenden en kötü performans gösterene göre sıralanmaktadır. İhracat performansını yansıtacağı düşünülen pek çok 
gösterge mevcut olmakla birlikte, dünya çapında tüm ülkeler için benzer döneme ait verilerin mevcudiyeti seçilen gösterge sayısını kısıtlamaktadır. Ayrıca performans ölçütü olarak seçilen tüm göstergelerin ihracat performansını eşit derecede etkilemeyeceği düşünülerek yine söz konusu göstergeler kendi aralarında ağırlıklandırılmıştır. Ağırlıklandırma işlemi için bulanık AHP yöntemi tercih edilmiştir. Göstergelerin ağırlıklandırması sürecinde uzman görüşlerine başvurulmuş olup, böylece performans ölçütlerinin ve önem derecelerinin belirlenmesinde konusunda uzman durumdaki farklı sayıda kişinin değerlendirmeleri tek potada eritilmiştir. Kullanılan bulanık AHP ve TOPSIS yöntemlerine ait bilgiler takip eden yönteme ilişkin bölümde detaylı olarak verilmiştir.
İhracat ile ilgili göstergeler Dünya Bankasının WDI veri tabanından temin edilmiş olup, ilgili göstergelerin tamamı için en güncel veriler 2013 yılına aittir. Dolayısıyla çalışma, ülkelerin 2013 yılındaki ihracat performanslarını ölçecektir. Kullanılacak göstergeler Tablo 2'de listelenmiştir. Çalışmada ilgili ülkelerin ihracat performansı Tablo 2'de verilen göstergeler ışı̆̆ında belirlenecektir. Göstergelerin önemli bir kısmının oran şeklinde olması, çalışma sonucunda ülkelerin ölçekleri ve olanakları bakımından ihracat performanslarının görülmesini mümkün kılacaktır.

Çalışmada kullanılan veriler ilgili ülke grubu için temin edilebilen tüm verileri kapsamaktadır. Dolayısıyla çalışmanın uygulama bölümünde yapılan analiz

Tablo 2. Performans Ölçütü Olarak Kullanılan Göstergeler

\begin{tabular}{|c|c|c|}
\hline Gösterge & Açıklaması & Verinin Kaynağı \\
\hline IND & İhracat Değer Endeksi $(2000=100)$ & $\begin{array}{l}\text { BM Ticaret ve Kalkınma Konferans1,"Handbook of Stats. } \\
\text { and Data Files" ve IMF, "Int. Financial Stats." }\end{array}$ \\
\hline COST & Konteynır Başına İhr. Maliyeti (\$) & Dünya Bankası, "Doing Business Project" \\
\hline DOC & İhracat İcin Gereken Doküman Sayısı & Dünya Bankası, "Doing Business Project" \\
\hline HINC & $\begin{array}{l}\text { Yüksek Gelirli Ülkelere Mal İhr. (Mal } \\
\text { İhr. İçindeki \%'si) }\end{array}$ & $\begin{array}{l}\text { IMF’nin "Direction of Trade" veri tabanı kullanılarak } \\
\text { Dünya Bankası tarafından hesaplanmıştır. }\end{array}$ \\
\hline GANDS & $\begin{array}{l}\text { Mal ve Hizmet İhr. (GDP içindeki } \\
\text { \%’si) }\end{array}$ & $\begin{array}{l}\text { Dünya Bankası "National Accounts" verileri ve OECD } \\
\text { "National Accounts" verileri. }\end{array}$ \\
\hline НТЕСН & $\begin{array}{l}\text { Yüksek Teknoloji Ürünleri İhr. } \\
\text { (Sanayi Ürünleri İhr. İçindeki \%’si) }\end{array}$ & BM, "Comtrade" veri tabanı. \\
\hline MANUF & $\begin{array}{l}\text { Sanayi Ürünleri İhr. (Mal İhr. İçindeki } \\
\text { \%’si) }\end{array}$ & $\begin{array}{l}\text { BM İstatistik departmanına ait "Comtrade" veri tabanı } \\
\text { kullanılarak Dünya Bankası tarafindan hesaplanmıştır. }\end{array}$ \\
\hline
\end{tabular}

ulaşılabilen verilerin yansıttığ maktadır. Çalışmaya konu 22 ülke içerisinde söz konusu göstergelerde ilk 5 sirada yer alan ülkeler Tablo 3’te sıralanmıştır.

Tablo 3’ten de gözlenebileceği gibi, tüm göstergelerde ilk 5 sırada yer alan ülkelere bakıldığında sadece 14 farklı ülkenin mevcut olduğu görülmektedir. Yani, analize dâhil olan 22 ülkeden 8 tanesi hiçbir kategoride ilk 5 arasında yer alamamıştır. Bununla birlikte; Macaristan, Malezya, Filipinler ve Polonya 4 farklı kategoride ilk 5 arasında yer almış olup, bu ülkeleri 3 kategori ile Bulgaristan, Çin ve Tayland izlemektedir. Ayrıca 3 ülke 2'şer kategoride lider ülke konumunda olmakla birlikte, bu ülkeler ihracat değer endeksi ve sanayi ürünleri ihracatında Çin, konteynır başına maliyet ve gerekli doküman sayısında Malezya ve yüksek gelirli ülkelere ihracat ve gerekli doküman sayısında ise Meksika'dır. Gerekli doküman sayısında toplam 5 ülke 4 rakamıla lider ülke konumundadır. Bu kategoride 6 ile 11. sıra arasında kalan 6 ülkede ise ihracat için gerekli olan doküman sayısı 5 'tir.

Literatürde ülke performanslarının AHP, WSA, TOPSIS, VIKOR, PROMETHEE ve MAUT gibi yöntemler kullanılarak ölçüldüğü pek çok çalışma mevcuttur. Bu çalışma da konusu itibarıyla bu kategoriye giren bir çalışmadır. Benzer şekildeki çalışmaların genel olarak 2010 yılı ve sonrasında yapılmış olduğu yapılan literatür taramasında gözlenmiş olup, Tablo 4'de çeşitli ülke gruplarının belirli alanlarda performanslarının karşılaştırıldığı çalışmaların listesi sunulmuştur. 
Tablo 3. Ihracat Göstergelerine Göre Illk 5 Ülke (2013)

\begin{tabular}{|c|c|c|c|c|c|c|c|c|c|c|c|c|c|c|}
\hline \multirow{2}{*}{$\begin{array}{l}\text { S. } \\
\text { N. } \\
1\end{array}$} & \multicolumn{2}{|c|}{ IND $(2000=100)$} & \multicolumn{2}{|l|}{$\operatorname{CosT}(\$)$} & \multicolumn{2}{|l|}{ DOC (Sayı) } & \multicolumn{2}{|l|}{ HINC (\%) } & \multicolumn{2}{|c|}{ GANDS (\%) } & \multicolumn{2}{|c|}{ НTECH (\%) } & \multicolumn{2}{|c|}{ MANUF (\%) } \\
\hline & Çin & 887 & Malezya & 450 & Malezya & 4 & Meksika & 90 & Macaristan & 88 & Filipinler & 47 & Çin & 94 \\
\hline 2 & Hindistan & 737 & Filipinler & 585 & Endonezya & 4 & Polonya & 87 & Malezya & 76 & Malezya & 44 & Macaristan & 82 \\
\hline 3 & Polonya & 636 & Tayland & 595 & Bulgaristan & 4 & Macaristan & 82 & Tayland & 68 & Çin & 27 & Türkiye & 78 \\
\hline 4 & Romanya & 632 & Endonezya & 595 & Meksika & 4 & Romanya & 77 & Bulgaristan & 67 & Tayland & 20 & Filipinler & 78 \\
\hline 5 & Bulgaristan & 607 & Pakistan & 765 & Kolombiya & 4 & Filipinler & 76 & Polonya & 46 & Macaristan & 16 & Polonya & 77 \\
\hline
\end{tabular}

Tablo 4. Ülkeler Bazında Performans Değerlendirmesi Yapılan Çalısmaların Literatür Özeti

\begin{tabular}{|c|c|c|c|}
\hline Yazar & Yöntem & Ülkeler ve Dönem & Konu \\
\hline Kaya vd., (2011) & VIKOR & $\begin{array}{l}\text { AB ülkeleri + Makedonya, } \\
\text { Hirvatistan, Norveç ve Türkiye 2003, } \\
2005 \text { ve } 2007\end{array}$ & Yaşam kalitesi \\
\hline Dinçer, (2011) & $\begin{array}{l}\text { TOPSIS ve } \\
\text { WSA }\end{array}$ & AB üye ve aday ülkeleri, 2008 & Ekonomik faaliyetler \\
\hline Mangir ve Erdogan, (2011) & $\begin{array}{l}\text { Bulanık } \\
\text { TOPSIS }\end{array}$ & $\begin{array}{l}\text { İtalya, Yunanistan, İspanya, Portekiz, } \\
\text { İrlanda ve Türkiye, 2002-2009 }\end{array}$ & $\begin{array}{l}\text { Küresel kriz döneminde } \\
\text { ekonomik performans }\end{array}$ \\
\hline Özden, (2012) & VIKOR & AB ülkeleri + Türkiye, 2010 & $\begin{array}{l}\text { Ekonomik gelişmişlikler } \\
\text { (Maastricht Kriterleri) }\end{array}$ \\
\hline $\begin{array}{l}\text { Huang ve } \\
\text { Peng, (2012) }\end{array}$ & TOPSIS & 9 Asya ülkesi, 2009 & Turist çekme rekabeti \\
\hline Jia vd., (2012) & $\begin{array}{l}\text { Bulanık AHP } \\
\text { ve TOPSIS }\end{array}$ & 47 ülke, 1990, 2000, 2005 ve 2007 & $\begin{array}{l}\text { Düşük karbonlu } \\
\text { kalkınma }\end{array}$ \\
\hline $\begin{array}{l}\text { Çakır ve } \\
\text { Perçin, (2013) }\end{array}$ & $\begin{array}{l}\text { Entropi } \\
\text { Ağırlık ve } \\
\text { TOPSIS }\end{array}$ & AB ülkeleri, 2006, 2008 ve 2009 & Ar-ge performansı \\
\hline $\begin{array}{l}\text { Genç ve } \\
\text { Masca, (2013) }\end{array}$ & $\begin{array}{l}\text { TOPSIS ve } \\
\text { PROMETHEE }\end{array}$ & AB ülkeleri + Türkiye, 2012 & $\begin{array}{l}\text { Ekonomik kriterlere göre } \\
\text { performans }\end{array}$ \\
\hline Samut, (2014) & $\begin{array}{l}\text { AHP ve } \\
\text { TOPSIS }\end{array}$ & OECD ülkeleri, 2009 & Eğitim performansı \\
\hline Paul vd., (2014) & TOPSIS & $\begin{array}{l}\text { Orta ve Doğu Avrupa ülkeleri, } 2007 \\
\text { ve } 2010\end{array}$ & $\begin{array}{l}\text { Doğrudan yabancı } \\
\text { yatırım çekme }\end{array}$ \\
\hline Balcerzak ve Pietrzak, (2014) & TOPSIS & AB'ye yeni üye ülkeler, 2000-2010 & $\begin{array}{l}\text { Bilgi tabanlı ekonomide } \\
\text { kurumsal etkinlik }\end{array}$ \\
\hline Önder vd., (2015) & $\begin{array}{l}\text { ANP ve } \\
\text { TOPSIS }\end{array}$ & Kirılgan 5'li, 2001-2013 & $\begin{array}{l}\text { Küresel kriz sonrası } \\
\text { ekonomik performans }\end{array}$ \\
\hline Balcerzak ve Pietrzak, (2015) & TOPSIS & 24 AB ülkesi, 2004-2010 & $\begin{array}{l}\text { İnsani gelişmişlik ve } \\
\text { kurum kalitesi }\end{array}$ \\
\hline Banihashemi ve Rejaei, (2015) & TOPSIS & Asya-İslam ülkeleri, 2011 & $\begin{array}{l}\text { Bilgi teknolojilerine } \\
\text { erişimimdeki eşitsizlik }\end{array}$ \\
\hline Eyüboğlu, (2016) & $\begin{array}{l}\text { AHP ve } \\
\text { TOPSIS }\end{array}$ & $\begin{array}{l}\text { Gelişmekte olan } 10 \text { ülke, 2003-2013 } \\
\text { arası }\end{array}$ & $\begin{array}{l}\text { Makroekonomik } \\
\text { performans }\end{array}$ \\
\hline Tunca,vd., (2016) & $\begin{array}{l}\text { Entropi ve } \\
\text { MAUT }\end{array}$ & 12 OPEC ülkesi & Ekonomik performans \\
\hline Balcerzak ve Pietrzak, (2016) & TOPSIS & AB ülkeleri, 2004 - 2013 & Sürdürülebilir kalkınma \\
\hline Pietrzak ve Balcerzak, (2016) & TOPSIS & AB'ye yeni üye ülkeler, 2000-2010 & $\begin{array}{l}\text { Beşeri sermaye ve toplam } \\
\text { faktör verimliliği }\end{array}$ \\
\hline
\end{tabular}

Tablo 4'ten de izlenebileceği gibi, ülkeler bazında yapılan performans analizleri ağırlıklı olarak ekonomik performansları ölçmeye yöneliktir. Söz konusu çalışmalar büyük oranda $\mathrm{AB}$ ülkeleri için yapılmakla birlikte, literatürde diğer ülke grupları için yapılan çalışmalar da mevcuttur. Yapılan literatür taraması sonucu ekonomik göstergeler dışında; eğitim, insani gelişmişlik, yaşam kalitesi ve turizm gibi alanlarda da performans değerlendirmeleri yapıldığı gözlenmiştir. Buna karşılık, ülkelerin ihracat performansını ölçme- 
ye yönelik yapılmış herhangi bir çalışmaya ise rastlanılmamıştır. Bu çalışma ile literatüre bu alanda katkı yapılması amaçlanmaktadır.

\section{Yöntem}

\section{Bulanık Mantık}

Klasik küme mantığında 0 bir elemanın kümeye ait olmamasını, 1 ise kümeye aitliği göstermektedir. Bulanık kümede ise, elemanın $[0,1]$ arasında gerçek bir sayı almasıyla kümeye üyelik derecesi gösterilir (Zadeh, 1965, s. 339-340). Klasik mantıkta ifadeler ve ilişkilerin net olduğu düşünülmektedir. "Hava sıcak" diye tabir edildiği zaman herkes için sıcak olduğu varsayılmaktadır. Ancak gerçekte dilsel ifadeler farklılıklar içermektedir. Aynı durum için farklı bireyler değişik yanitlar vereceklerdir. Bu belirsizlik durumu, özellikle karar verme aşamasında gerçekliğe dönüştürülmeli ve sayisal olarak ifade edilmelidir (Tsaur, Chang ve Yen, 2002, s. 110; Aydın, 2009, s. 89; Yllmaz, 2012, s. 338). Bunun için Zadeh (1965) tarafından bulanık küme teorisi ortaya atılmıştır. Ardından Bellman ve Zadeh (1970) tarafindan karar verme problemlerinde bulanık mantığın nasıl kullanılacağı tanımlanmış ve günümüze kadar çok sayıda çalışma yapılıışıtır.

Bulanık mantıktaki dilsel ifadeler bulanık sayılar ile sayısal ifadelere dönüștürülür. Bu ifadeleri dönüştürmek için; üçgen, yamuk veya çan eğrisi şeklinde bulanık sayılar kullanılmaktadır (Yılmaz, 2012, s. 338). Şekil 1'de üyelik fonksiyonu görülen üçgen bulanık sayılarda "l" alt sinırı, "m" orta değeri ve "u" ise üst sinırı ifade etmektedir.

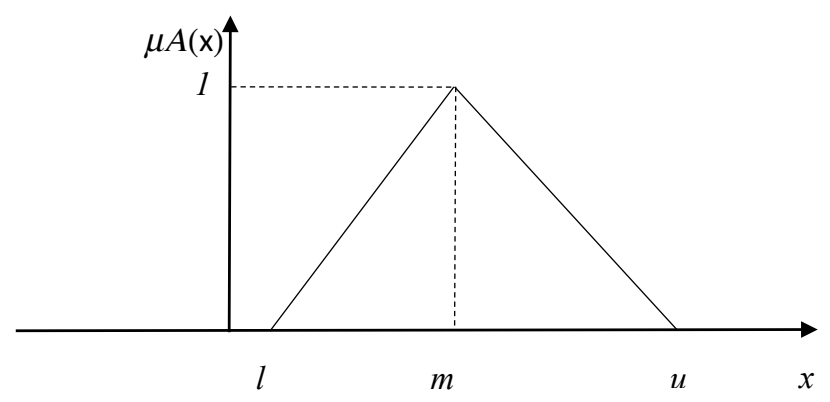

Şekil 1. Üçgen Bulanık Sayılar Üyelik Fonksiyonu

$A=\left(a_{1}, a_{2}, a_{3}\right)$ ve $B=\left(b_{1}, b_{2}, b_{3}\right)$ olmak üzere pozi-

tif üçgen bulanık sayılar olsun.

Tersini alma işlemi:

$A^{-1}=\left(\frac{1}{a_{3}}, \frac{1}{a_{2}}, \frac{1}{a_{1}}\right)$

Toplama:

$\oplus B=\left(a_{1}+b_{1}, a_{2}+b_{2}, a_{3}+b_{3}\right)$

Çıkarma:

$A(-) B=\left(a_{1}-b_{3}, a_{2}-b_{2}, a_{3}-b_{1}\right)$

Bir katsayı ile çarpımı:

$\forall k>0, k \in R, k A=\left(k a_{1}, k a_{2}, k a_{3}\right)$

$\forall k<0, k \in R, k A=\left(k a_{3}, k a_{2}, k a_{1}\right)$
Çarpma:

$A \otimes B=\left(a_{1} b_{1}, a_{2} b_{2}, a_{3} b_{3}\right)$

Bölme:

$$
\frac{A}{B}=\left(\frac{a_{1}}{b_{3}}, \frac{a_{2}}{b_{2}}, \frac{a_{3}}{b_{1}}\right)
$$

Bulanık sayılarda temel aritmetik işlemleri verilen eşitlikler ile yapılmaktadır (Deng, 1999, s. 217-218).

\section{Bulanık AHP}

AHP (Analitik Hiyerarşi Prosesi) Thomas Saaty tarafından 1970'li yıllarda geliştirilmiş, çok bilinen ve sık kullanılan, karmaşık problemleri çözmek için geliştirilmiş güçlü bir çok kriterli karar verme yöntemidir (Vaidya ve Kumar, 2006, s. 1; Karaoğlan ve Şahin, 2016, s. 361). İkili karşılaştırmalar temeline dayalı olan bu yöntemde hem nitel hem de nicel veriler değerlendirilebilmektedir. Yöntem, performans 
ölçütü olarak belirlenen kriterlerin üstünlüklerinin belirlenmesi ve sayısal tutarlılığının sağlanması aracılığıyla, birbirleri arasındaki ağırlıkların belirlenmesini mümkün kılmaktadır (Aydın vd., 2009, s. 72).

AHP yönteminin kesin mantık içermesi ve ikili karşlaştırmaların aslında kesinlik içermediği ve bulanık olduğu görüşüne dayanarak, Van Laarhoven ve Pedrycz (1983), Buckley (1985) ve Chang (1996) Bulanık AHP yöntemleri geliştirmişlerdir. Bulanık AHP yöntemi ilk olarak kriterlerin ikili karşılaştırmaları aşamasında AHP yönteminden farklılaşmaktadır.
Uzmanların bir konudaki görüşlerini kesin bir sayı yerine sözel değerlendirmelerle vermelerinin daha gerçekçi olacağından hareketle, bu sözel değerlendirmelerin yargı aralığını belirlemek için üçgen bulanık sayılar kullanılmaktadır (Sofyalığlu, 2009).

Buckley (1985) yöntemine göre Bulanık AHP yönteminin basamakları şöyledir (Ayhan, 2013, s. 10):

1. Adım: Karar vericiler, kriterleri veya alternatifleri aşağıda verilmiş olan Tablo 5’e göre karşılaştırırlar.

Tablo 5. Dilsel Iffadeler, Saaty (1977, s. 246) Ölçeği ve Bulanık Karşılıkları

\begin{tabular}{ccccc}
\hline & \multicolumn{2}{c}{ AHP } & \multicolumn{2}{c}{ Bulanık AHP } \\
\hline Dilsel İfadeler & Ölçek & Karşı̈lı Ölçeği & Ölçek & Karşılık Ölçeği \\
Eşit Derecede Önemli & 1 & 1 & $1,1,1$ & $1,1,1$ \\
Orta Derecede Önemli & 3 & $1 / 3$ & $2,3,4$ & $1 / 4,1 / 3,1 / 2$ \\
Güçlü Derecede Önemli & 5 & $1 / 5$ & $4,5,6$ & $1 / 6,1 / 5,1 / 4$ \\
Çok Güçlü Derecede Önemli & 7 & $1 / 7$ & $6,7,8$ & $1 / 8,1 / 7,1 / 6$ \\
Son Derece Önemli & 9 & $1 / 9$ & $9,9,9$ & $1 / 9,1 / 9,1 / 9$ \\
\hline
\end{tabular}

İkili karşılaştırmaların ardından "Bulanık İkili Karşlaştırma Matrisi” oluşturulur. Karar verici sayısının birden fazla olması durumunda, karar vericilerin verdiği yanıtların sayısal değerlerinin geometrik ortalamaları alınır ve sonuçta matrisi elde edilir.

$\tilde{A}=\left[\begin{array}{cccc}d_{11} & d_{12} & \cdots & d_{1 n} \\ d_{21} & d_{22} & \cdots & d_{2 n} \\ \vdots & \vdots & \ddots & \vdots \\ d_{m 1} & d_{m 2} & \cdots & d_{m n}\end{array}\right]$

2. Adım: Bulanık değerlerin geometrik ortalamaları,

$$
\tilde{r}_{i}=\left(\prod_{j=1}^{n} \tilde{d}_{i j}\right)^{1 / n}, \quad i=1,2, \ldots, n
$$

eşitliği ile hesaplanır. Burada hâlâ üçgen değerleri ifade etmektedir.

3. Adım: Her kriterin bulanık ağılıklarını elde etmek için,

$\widetilde{w}_{i}=\tilde{r}_{i} \otimes\left(\tilde{r}_{1} \oplus \tilde{r}_{2} \oplus \ldots \oplus \tilde{r}_{n}\right)^{-1}$

eşitliği ile $l w_{i}, m w_{i} v e u w_{i}$ değerleri elde edilmiş olur.
4. Adım: $\widetilde{w}_{i}$ yani $l w_{i} m w_{i}$ ve $u w_{i}$ değerleri hâlâ üçgen bulanık sayılardır. Bu sayıları bulanıklıktan kurtarmak için,

$M_{i}=\frac{l w_{i}+m w_{i}+u w_{i}}{3}$

eşitliği ile değerleri elde edilir ve bu değerler,

$$
w_{i}=\frac{M_{i}}{\sum_{i=1}^{n} M_{i}}
$$

eşitliği ile normalleştirilerek her bir kritere veya alternatiflere ait ağırlıklar elde edilmiş olur.

\section{TOPSIS}

TOPSIS (Technique for Order Preference by Similarity to an Ideal Solution) yöntemi, Hwang ve Yoon tarafından 1981 yılında çok kriterli karar verme problemlerini çözmek amacıyla geliştirilmiştir (Chen, 2000, s. 2; Demireli, 2010, s. 104). TOPSIS, bir alternatifi, pozitif ve negatif ideal çözüme nispi uzaklıklarına göre sıralayan bir yöntemdir (Zanakis vd., 1998, s. 510-511; Shih, vd., 2007, s. 801).

Birbirlerinden bağımsız olması gerekmeyen ancak ölçülebilir olması gereken alternatiflerin performans 
ölçütlerinin çift yönlü olarak görülebilmesi, en iyi ve en kötü değerlerin hesaba katılabilmesi ve mantığ temsil edebilmesi diğer çok kriterli karar verme yöntemlerine göre TOPSIS yönteminin üstünlükleri olarak siralanabilir (Kim, vd., 1997, s. 27; Shih vd., 2007, s. 802). Hem bu üstünlükleri hem de geniş kullanım alanı bulabilmesi sebebiyle TOPSIS en sık kullanılan yöntemlerden birisi haline gelmiştir.

Öncelikle alternatifler arasından en iyisini seçmek amacıyla bir çok kriterli karar verme yöntemi olarak geliştirilmesine rağmen (Behzadian vd., 2012,s. 13051), TOPSIS'in performans analizi çalışmalarında da sıklıkla kullanıldığı görülmüştür.

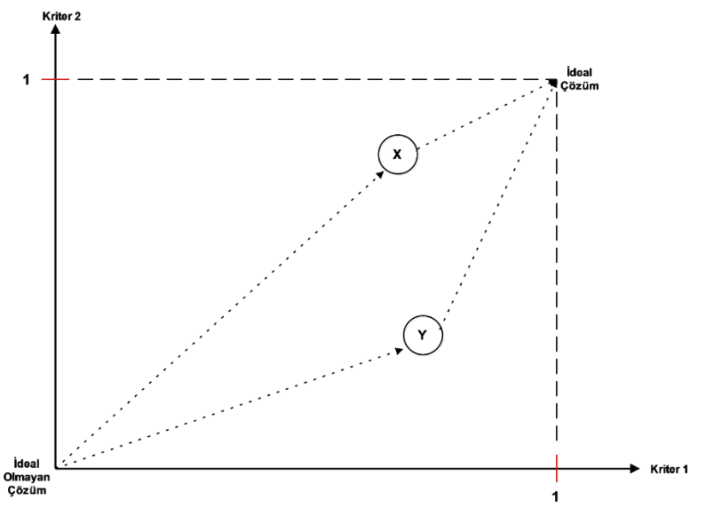

Şekil 2. TOPSIS Yönteminin Çalışma Prensibi

TOPSIS yöntemi, karar matrisinin oluşturulması ile başlayan 6 adımdan oluşmaktadır (Jahanshahloo, vd., 2006, s. 1378; Ustasüleyman, 2009, s. 37-38; Behzadian vd., 2012, s. 13052):

1. Adım: Karar matrisi oluşturulur.

$$
A_{i j}=\left[\begin{array}{cccc}
a_{11} & a_{12} & \cdots & a_{1 n} \\
a_{21} & a_{22} & \cdots & a_{2 n} \\
\vdots & \vdots & \ddots & \vdots \\
a_{m 1} & a_{m 2} & \cdots & a_{m n}
\end{array}\right]
$$

2. Adım: Normalizasyon aşamasıdır. Bu aşamada her bir alternatif için;

$R_{i j}=\frac{a_{i j}}{\sqrt{\sum_{i=1}^{m} a_{i j}^{2}}}$

eşitliği ile karar matrisindeki her bir değer, kendi sütunundaki değerlerin toplamının kareköküne oranlanarak yeni bir matris elde edilir ve bu matrise "Normalize Karar Matrisi” denilmektedir.
3. Adım: "Ağırlıklandırılmış Normalize Karar Matrisi"ni elde etmek için, Bulanık AHP yöntemi ile hesaplanmış olan kriter ağırlıkları matrisi ile 1. adımda elde edilen "Normalize Karar Matrisi" çarpılır.

$V_{i j}=R_{i j} \times w_{i j}$

4. Adım: Bu aşamada Pozitif ve Negatif İdeal Çözümler elde edilmektedir.

$A^{*}=\left\{\left(\max V_{i j} \mid j \in J\right\}\right.$

$A^{-}=\left\{\left(\min V_{i j} \mid j \in J\right\}\right.$

eşitlikleri ile her bir kriter için maksimum ve minimum değerler elde edilir. Kriterin fayda kriteri olması durumunda o kritere ait en büyük alternatif değeri, maliyet kriteri olması durumunda ise o kritere ait en küçük değer $A^{*}$ olarak kullanılmaktadır.

5. Adım: Ayrım ölçülerinin hesaplanması adımıdır. Her bir alternatif için;

$$
\begin{aligned}
& S_{i}^{*}=\sqrt{\sum_{j=1}^{n}\left(v_{i j}-v_{j}^{+}\right)^{2}} \\
& S_{i}^{-}=\sqrt{\sum_{j=1}^{n}\left(v_{i j}-v_{j}^{-}\right)^{2}}
\end{aligned}
$$

eşitlikleri ile pozitif ideal noktaya olan uzaklıklar $\left(S^{*}\right)$ ve negatif ideal noktaya olan uzaklıklar $(S)$ hesaplanmaktadır.

6. Adım: Son aşamada ise, ideal çözüme nispi yakınlığı gösteren $C_{i}^{*}$ değeri;

$$
C_{i}^{*}=\frac{S_{i}^{-}}{S_{i}^{*}+S_{i}^{-}}, \quad 0<C_{i}^{*}<1
$$

eşitliği ile elde edilecektir. Belirlenen bu $C_{i}^{*}$ değeri 0 ile 1 arasında yer alacak olup, elde edilen değere göre alternatifler sıralanmaktadır.

\section{Uygulama}

Çalışmanın bu bölümünde gelişmekte olan piyasa ekonomileri sinıflandırmasına dâhil olan 22 ülke, Tablo 2'de verilmiş olan 7 karar kriteri kapsamında ihracat performanslarının karşılaştırmasına tabi tutulacaktır. Karar kriterleri uluslararası ticaret ve ihracat konusunda uzman kişiler tarafından değerlendirilmiştir. 4 uzman kişiden oluşan yanıtlayıcı grubu birbirlerinden bağımsız olarak değerlendirme yapmışlardır ve her bir uzmanın değerlendirmesi ekte sunulmuştur (Ek-1). Uzmanların her biri konu 
hakkında akademik yetkinliğe sahiptir ve ortalama deneyimleri 13,5 yıldır. Ardından kriter ağırlıkları Bulanık AHP yöntemi ile hesaplanmıștır. Karar vericilerin dilsel ifadelerinin netlik içermemesi ve sübjektif değerlerin bir miktar daha objektif olabilmesi için bu çalışmada Bulanık AHP yöntemi, performans değerlendirme çalışmaları da dahil olmak üzere literatürde kriter ağırlıklandırma yöntemi olarak sıklıkla kullanılan AHP yöntemi yerine tercih edilmiştir. Uz- man görüşlerine dayanmayan kriter ağırlıklandırma yöntemleri ise sonuçların gerçek önem derecelerini yansıtmayacağı çekincesi ile değerlendirilmemiștir. Ardından da 22 ülkeye ait göstergeler, TOPSIS yöntemi ile değerlendirilmiştir.

İlk aşama olarak, uzmanlar tarafından yapılan ikili karşılaştırmalar sonucunda "Bulanık İkili Karşılaştırma Matrisi” elde edilmiş olup Tablo 6'da verilmiştir.

Tablo 6. Bulanık İili Karşılaştırma Matrisi

\begin{tabular}{|c|c|c|c|c|c|c|c|}
\hline & IND & COST & DOC & HINC & GANDS & НТЕСН & MANUF \\
\hline IND & $1,001,001,0$ & $4,365,336,24$ & $5,056,036,93$ & $\left|\begin{array}{lll}0,17 & 0,21 & 0,27\end{array}\right|$ & $2,052,492,9$ & $\mid \begin{array}{lll}0,34 & 0,40 & 0,47\end{array}$ & $0,87 \quad 1,06 \quad 1,30$ \\
\hline COST & & & $3,464,535,57$ & & & & $0,14 \quad 0,16 \quad 0,20$ \\
\hline DOC & $0,140,170,20$ & $0,180,220,29$ & $1,001,001,00$ & $0,140,160,20$ & 160,20 & $0,130,140,15$ & $0,140,160,19$ \\
\hline HINC & $3,724,735,73$ & 6,90 & $5,096,127,14$ & 001,00 & 4702 & 150 & $3,25 \quad 3,76$ \\
\hline GANDS & $0,340,400,49$ & $4,955,966,96$ & $5,096,12$ & 0,140 , & 001,00 & 0,130 & $310,44 \quad 0,62$ \\
\hline НТЕСН & $2,142,512,91$ & $6,247,097,90$ & $6,647,307,90$ & $4,565,606,62$ & $6,006,857,67$ & $1,001,001,00$ & $4,865,896,90$ \\
\hline MANUF & {$[0,770,94 \quad 1,14$} & $5,096,127,14$ & $5,186,197,20$ & {$\left[\begin{array}{lll}0,27 & 0,31 & 0,37\end{array}\right]$} & $1,612,28 \quad 3,25$ & {$\left[\begin{array}{llll}0,14 & 0,17 & 0,21\end{array}\right.$} & $1,00 \quad 1,00 \quad 1,00$ \\
\hline
\end{tabular}

"Bulanık İkili Karşılaştırma Matrisi” düzenlendikten sonra, bulanık $\tilde{d}_{i j}$ değerlerinin Eşitlik 9 kullanılarak geometrik ortalamaları alınmış ve $\tilde{r}_{i}$ değerleri elde edilmiştir. Örneğin, IND kriteri için $\tilde{r}_{i}$ değeri;

$$
\begin{aligned}
& \tilde{r}_{i} \quad=\left[(1 * 4,36 * 5,05 * 0,17 * 2,05 * 0,34 * 0,87)^{1 / 7}\right. \text {; } \\
& \left.(n))^{1 / n} \quad(1 * 5,33 * 6,03 * 0,21 * 2,49 * 0,40 * 1,06)^{1 / 7} ;(1 * 6,24 * 6,93 * 0,27 * 2,98 * 0,47 * 1,30)^{1 / 7}\right] \\
& =\left(\prod_{j=1}^{n} \tilde{d}_{i j}\right)^{1 / n}=[1,13 ; 1,32 ; 1,54]
\end{aligned}
$$

\begin{tabular}{|c|c|c|c|}
\hline \multirow{2}{*}{$\frac{\text { Kriterler }}{\text { IND }}$} & \multicolumn{3}{|c|}{$\tilde{\boldsymbol{r}}_{i}$} \\
\hline & 1,13 & 1,32 & 1,54 \\
\hline COST & 0,30 & 0,34 & 0,40 \\
\hline DOC & 0,19 & 0,22 & 0,25 \\
\hline HINC & 2,17 & 2,52 & 2,88 \\
\hline GANDS & 0,65 & 0,76 & 0,89 \\
\hline НТЕСН & 3,82 & 4,35 & 4,86 \\
\hline MANUF & 1,03 & 1,23 & 1,47 \\
\hline TOPLAM & 9,28 & 10,74 & 12,28 \\
\hline Katsayı & 0,08 & 0,09 & 0,11 \\
\hline
\end{tabular}

olarak hesaplanmış ve tüm kriterler için sonuçlar Tablo 7'de verilmiştir.

Aynı zamanda Tablo 7'de değerlerinin toplamları ve "Katsayı" satırında da "Toplam" satırının tersi verilmiştir.
Ardından Eşitlik 10 ile bulanık ağırlıkları gösteren değerleri, Eşitlik 11 ile ağırlıkları gösteren değerleri ve Eşitlik 12 ile de normalize ağırlıkları gösteren değerleri yani kriter ağırlıkları elde edilmiştir ve bu değerler Tablo 8'de verilmiştir. Tablo 8'deki değerleri her bir kriterin sistem içindeki ağırlık yüzdesini vermekte olup toplamları 1'e eşittir.

Tablo 8. Bulanık Ağırıklar ve Kriter Ağırlıkları Tablosu

\begin{tabular}{lrrrrr}
\hline Kriterler & $\boldsymbol{l w}_{\boldsymbol{i}}$ & $\boldsymbol{m}_{\boldsymbol{i}}$ & $\boldsymbol{u} \boldsymbol{w}_{\boldsymbol{i}}$ & $\boldsymbol{M}_{\boldsymbol{i}}$ & $\boldsymbol{w}_{\boldsymbol{i}}$ \\
\hline IND & 0,09 & 0,12 & 0,17 & 0,13 & $\mathbf{0 , 1 2}$ \\
COST & 0,02 & 0,03 & 0,04 & 0,03 & $\mathbf{0 , 0 3}$ \\
DOC & 0,02 & 0,02 & 0,03 & 0,02 & $\mathbf{0 , 0 2}$ \\
HINC & 0,18 & 0,23 & 0,31 & 0,24 & $\mathbf{0 , 2 3}$ \\
GANDS & 0,05 & 0,07 & 0,10 & 0,07 & $\mathbf{0 , 0 7}$ \\
HTECH & 0,31 & 0,40 & 0,52 & 0,41 & $\mathbf{0 , 4 0}$ \\
MANUF & 0,08 & 0,11 & 0,16 & 0,12 & $\mathbf{0 , 1 2}$ \\
\hline
\end{tabular}


Kriter ağırlıklarının hesaplanmasından sonra alternatiflerin değerlendirilmesi aşamasına geçilmiştir. $\mathrm{Bu}$ aşamada öncelikle "Karar Matrisi" oluşturulmuştur ve bu karar matrisinde, performansları siralanacak olan piyasa ekonomileri sinıflandırmasına dâhil olan 22 ülke ve bu ülkelerin çalışmada kullanılan 7 göstergeye ait verileri görülmektedir (Tablo 9).

Tablo 9. Karar Matrisi

\begin{tabular}{lrrrrrrr}
\hline & IND & COST & DOC & HINC & GANDS & HTECH & MANUF \\
\hline Brezilya & 439,37 & 2414,3 & 6 & 58,57 & 12,02 & 9,63 & 36,37 \\
Cin & 886,68 & 823 & 8 & 74,53 & 23,32 & 26,97 & 94,02 \\
Hindistan & 737,17 & 1332 & 7 & 61,64 & 25,16 & 8,07 & 61,88 \\
Endonezya & 280,64 & 595,2 & 4 & 58,95 & 23,98 & 7,05 & 37,80 \\
Meksika & 228,52 & 1499,3 & 4 & 90,49 & 31,86 & 15,92 & 76,25 \\
Pakistan & 278,58 & 765 & 8 & 58,33 & 13,28 & 1,88 & 74,01 \\
Filipinler & 141,75 & 585 & 6 & 76,45 & 28,01 & 47,11 & 77,69 \\
Rusya & 498,25 & 2337,5 & 9 & 67,19 & 28,62 & 10,01 & 16,58 \\
G. Afrika & 320,43 & 1705 & 5 & 43,46 & 30,98 & 5,47 & 45,88 \\
Türkiye & 546,58 & 990 & 7 & 58,51 & 25,64 & 1,88 & 78,08 \\
Arjantin & 315,20 & 1650 & 6 & 40,02 & 14,32 & 9,84 & 33,06 \\
Bulgaristan & 607,41 & 1375 & 4 & 62,56 & 66,98 & 7,96 & 48,07 \\
Şili & 402,74 & 980 & 5 & 52,84 & 32,41 & 4,90 & 13,73 \\
Kolombiya & 450,97 & 2355 & 4 & 63,59 & 17,62 & 7,39 & 17,59 \\
Macaristan & 383,69 & 885 & 6 & 82,31 & 87,96 & 16,34 & 82,30 \\
Malezya & 232,39 & 450 & 4 & 61,72 & 75,61 & 43,57 & 60,78 \\
Peru & 601,39 & 890 & 5 & 64,46 & 24,13 & 3,57 & 14,58 \\
Polonya & 636,45 & 1050 & 5 & 87,27 & 46,30 & 7,71 & 76,85 \\
Romanya & 632,30 & 1485 & 5 & 76,56 & 39,74 & 5,72 & 75,84 \\
Tayland & 331,38 & 595 & 5 & 55,34 & 67,71 & 20,09 & 74,95 \\
Ukrayna & 434,46 & 1930 & 8 & 55,70 & 42,96 & 5,89 & 58,71 \\
Venezuela & 258,58 & 3490 & 8 & 47,45 & 24,76 & 1,13 & 1,82 \\
\hline
\end{tabular}

Karar matrisinin elde edilmesi aşamasından sonra, TOPSIS yöntemindeki işlem adımları takip edilir ve öncelikle Eşitlik 13 kullanılarak "Normalize Karar Matrisi" elde edilir.

Tablo 10. Ağırlıklandırılmış Normalize Karar Matrisi

\begin{tabular}{lrrrrrrr}
\hline & IND & COST & DOC & HINC & GANDS & HTECH & MANUF \\
\hline Brezilya & 2,44 & 1,06 & 0,43 & 4,51 & $\mathbf{0 , 4 5}$ & 4,81 & 1,52 \\
Cin & $\mathbf{4 , 9 3}$ & 0,36 & 0,57 & 5,74 & 0,86 & 13,46 & $\mathbf{3 , 9 3}$ \\
Hindistan & 4,10 & 0,58 & 0,50 & 4,75 & 0,93 & 4,03 & 2,59 \\
Endonezya & 1,56 & 0,26 & $\mathbf{0 , 2 9}$ & 4,54 & 0,89 & 3,52 & 1,58 \\
Meksika & 1,27 & 0,66 & $\mathbf{0 , 2 9}$ & $\mathbf{6 , 9 7}$ & 1,18 & 7,95 & 3,19 \\
Pakistan & 1,55 & 0,34 & 0,57 & 4,49 & 0,49 & 0,94 & 3,10 \\
Filipinler & $\mathbf{0 , 7 9}$ & 0,26 & 0,43 & 5,89 & 1,04 & $\underline{\mathbf{2 3 , 5 1}}$ & 3,25 \\
Rusya & 2,77 & 1,02 & $\mathbf{0 , 6 4}$ & 5,17 & 1,06 & 4,99 & 0,69 \\
G. Afrika & 1,78 & 0,75 & 0,36 & 3,35 & 1,15 & 2,73 & 1,92 \\
Türkiye & 3,04 & 0,43 & 0,50 & 4,51 & 0,95 & 0,94 & 3,27 \\
Arjantin & 1,75 & 0,72 & 0,43 & $\mathbf{3 , 0 8}$ & 0,53 & 4,91 & 1,38 \\
Bulgaristan & 3,38 & 0,60 & $\mathbf{0 , 2 9}$ & 4,82 & 2,48 & 3,97 & 2,01 \\
Şili & 2,24 & 0,43 & 0,36 & 4,07 & 1,20 & 2,44 & 0,57 \\
Kolombiya & 2,51 & 1,03 & 0,29 & 4,90 & 0,65 & 3,69 & 0,74 \\
Macaristan & 2,13 & 0,39 & 0,43 & 6,34 & $\mathbf{3 , 2 6}$ & 8,16 & 3,44 \\
Malezya & 1,29 & $\mathbf{0 , 2 0}$ & $\mathbf{0 , 2 9}$ & 4,75 & 2,80 & 21,75 & 2,54 \\
Peru & 3,34 & 0,39 & 0,36 & 4,96 & 0,89 & 1,78 & 0,61 \\
Polonya & 3,54 & 0,46 & 0,36 & 6,72 & 1,71 & 3,85 & 3,22 \\
Romanya & 3,52 & 0,65 & 0,36 & 5,90 & 1,47 & 2,85 & 3,17 \\
Tayland & 1,84 & 0,26 & 0,36 & 4,26 & 2,51 & 10,03 & 3,14 \\
Ukrayna & 2,42 & 0,85 & 0,57 & 4,29 & 1,59 & 2,94 & 2,46 \\
Venezuela & 1,44 & $\mathbf{1 , 5 3}$ & 0,57 & 3,65 & 0,92 & $\mathbf{0 , 5 6}$ & $\mathbf{0 , 0 8}$ \\
\hline
\end{tabular}

* Altı çizili ve koyu renkli olan değerler, kritere ait olan en iyi değeri, eğik ve koyu renkli olan değerler ise en kötü değeri göstermektedir. 
Ardından Bulanık AHP yöntemi ile hesaplanmış olan ve Tablo 8'de verilen kriter ağırlıkları ile "Normalize Karar Matrisi” Eşitlik 14 kullanılarak çarpılır. Bu işlemler sonucunda, Pozitif ve Negatif İdeal çözümleri bulmak için kullanacak "Ağırlıklandırılmış Normalize Karar Matrisi” oluşturulur. Bu matris oluşturulurken hesaplamaların kolay yapılabilmesi için kriter ağırlıklarının yüz katı kullanılmıştır.

Ağırlıklandırılmış normalize karar matrisinin elde edilmesinin ardından Tablo 10'da koyu renkli olarak verilmiş olan pozitif ve negatif ideal çözümler, Eşitlik 15 ve Eşitlik 16 vasitasıyla hesaplanır.

Fayda kriterleri; IND, HINC, GANDS, HTECH ve MANUF için en büyük değerler "Pozitif İdeal Çö- züm" değeri olarak hesaplanmışken, maliyet kriterleri COST ve DOC için en küçük değerler "Pozitif İdeal Çözüm" değeri olarak elde edilmiş ve Tablo 11'de "Negatif İdeal Çözüm” değerleriyle birlikte verilmiştir.

Bir sonraki aşamada ise Eşitlik 17 ve Eşitlik 18 kullanılarak ayrım ölçüleri olarak adlandırılan, pozitif ideal noktaya olan uzaklıklar olan $S_{i}^{*}$ değerleri ve negatif ideal noktaya uzaklıklar olan $S_{i}^{-}$değerleri hesaplanmıştır.

Son aşamada ise $S_{i}^{*}$ ve $S_{i}^{-}$değerleri Eşitlik 19 aracıllğıyla, ideal çözüme nispi uzaklıklar olan $C_{i}^{*}$ değerlerini elde etmek amacıyla kullanılmıștır. Bu ișlemlerin sonucunda ise elde edilen $C_{i}^{*}$ değerlerine göre ülkeler sıralanmış ve Tablo 12 'de verilmiștir.

Tablo 11. Pozitif ve Negatif Ideal Çözümler

\begin{tabular}{rrrrrrrr}
\hline & IND & COST & DOC & HINC & GANDS & HTECH & MANUF \\
\hline Poz.I. C. & 4,93 & 0,20 & 0,29 & 6,97 & 3,26 & 23,51 & 3,93 \\
Neg.I.CC & 0,79 & 1,53 & 0,64 & 3,08 & 0,45 & 0,56 & 0,08 \\
\hline
\end{tabular}

Tablo 12. İdeal Çözüme Uzaklıklar (Ihrracat Performansı Sonuçları)

\begin{tabular}{rlrrr}
\hline Sira & Ülkeler & $S_{i}^{*}$ & \multicolumn{1}{c}{$S_{i}^{-}$} & $C_{i}^{*}$ \\
\hline $\mathbf{1}$ & Filipinler & 4,873 & 23,381 & 0,82752 \\
$\mathbf{2}$ & Malezya & 4,838 & 21,571 & 0,81680 \\
$\mathbf{3}$ & Çin & 10,413 & 14,386 & 0,58010 \\
$\mathbf{4}$ & Tayland & 14,139 & 10,364 & 0,42297 \\
$\mathbf{5}$ & Macaristan & 15,631 & 9,522 & 0,37856 \\
$\mathbf{6}$ & Meksika & 16,148 & 9,000 & 0,35788 \\
$\mathbf{7}$ & Polonya & 19,794 & 6,654 & 0,25158 \\
$\mathbf{8}$ & Hindistan & 19,816 & 5,763 & 0,22532 \\
$\mathbf{9}$ & Rusya & 19,157 & 5,381 & 0,21928 \\
$\mathbf{1 0}$ & Bulgaristan & 19,832 & 5,497 & 0,21703 \\
$\mathbf{1 1}$ & Romanya & 20,831 & 5,666 & 0,21384 \\
$\mathbf{1 2}$ & Brezilya & 19,406 & 5,016 & 0,20538 \\
$\mathbf{1 3}$ & Arjantin & 19,632 & 4,718 & 0,19375 \\
$\mathbf{1 4}$ & Kolombiya & 20,514 & 4,109 & 0,16686 \\
$\mathbf{1 5}$ & Ukrayna & 21,027 & 4,149 & 0,16480 \\
$\mathbf{1 6}$ & Endonezya & 20,692 & 3,957 & 0,16055 \\
$\mathbf{1 7}$ & Türkiye & 22,917 & 4,347 & 0,15943 \\
$\mathbf{1 8}$ & Peru & 22,259 & 3,664 & 0,14135 \\
$\mathbf{1 9}$ & Pakistan & 23,143 & 3,642 & 0,13598 \\
$\mathbf{2 0}$ & Güney Afrika & 21,536 & 3,215 & 0,12991 \\
$\mathbf{2 1}$ & Şili & 21,798 & 2,954 & 0,11936 \\
$\mathbf{2 2}$ & Venezuela & 23,919 & 0,988 & 0,03968 \\
\hline & & & &
\end{tabular}

Tablo 12'de gösterilen sonuçlara göre, değeri yüksek olan ülkenin ihracat performansı daha yüksek, değeri düşük olan ülkenin ihracat performansı da daha düşüktür yorumu çıkmaktadır. Ayrıca tablodaki değeri tüm kriterlerin ağırlıklandırılmasının ardından oluşan en iyi çözüme, değeri ise en kötü çözüm kü- mesine olan mesafeyi göstermektedir. "Pozitif İdeal Çözüm” olarak adlandırılan en iyi çözüme yakın olmak ve "Negatif İdeal Çözüm" olarak adlandırılan en kötü çözüme uzak olmak ihracat performansı sonuçlarının yüksek olmasına sebep olmaktadır. 


\section{Sonuç ve Değerlendirme}

Gelişmekte olan ülkeler için son derece önemli bir hedef olan büyüme olgusunun en kritik unsurlarından biri olan ihracatın öneminden hareketle bu çalışmada, yükselen piyasa ekonomisi ülkelerinin 2013 yilı ihracat performansı ölçülmüş ve analize dâhil olan 22 ülke performanslarına göre sıralanmıştır. Analizde bulunan göstergelerin büyük çoğunluğunun orana dayalı veriler olması ülkelerin ölçekleri ve olanakları bakımından ihracat performanslarının görülmesini mümkün kılmıştır.

Çalışmada ilk olarak ihracat performansının ölçülmesi için kullanılmış olan göstergeler önem derecesine göre ağırlıklandırılmış olup, göstergeler en önemliden en önemsize göre; HTECH, HINC, IND, MANUF, GANDS, COST ve DOC şeklinde sıralanmıştır. Bulanık AHP yöntemi ile uzman görüşleri alınarak yapılan değerlendirme sonucunda belirlenen ağırlıklara göre, bürokrasi ile ilgili iki değişken (konteynır başına maliyet ve ihracat için gerekli doküman sayısı) en az önem atfedilen değişkenler olmuş ve ihracat aşamasında bürokrasinin bir şekilde aşılabileceği kanaatine varılmıştır. Bununla birlikte, en önemli göstergeler olarak ise yüksek teknoloji ürünlerinin ihracatı ve yüksek gelirli ülkelere yapılan ihracat göstergeleri ön plana çıkmıştır. TOPSIS yöntemi kullanılarak yapılan analiz sonucunda, HTECH göstergesi en yüksek ülke olan Filipinler belirlenen ağırlıkların da etkisiyle 2013 yılı itibarıyla ihracat performansı en iyi ülke olmuştur. Yine HTECH göstergesi en yüksek 6 ülke ayn zamanda ihracat performansı en iyi 6 ülke olarak sıralanmıştır. Bununla birlikte, performans açısından ilk 3 sırada yer alan diğer iki ülke olan Malezya ve Çin, ikişer göstergede (Malezya; COST ve DOC, Çin; IND ve MANUF) lider konumdadır. Skor puanı da göz önüne alındığında sıralamanın açık farkla son sırasında yer alan ülke olan Venezuela aynı zamanda tam 3 göstergede (COST, HTECH ve MANUF) performansı en kötü ülke durumundadır. Bu sonuçta en büyük etken olarak Venezuela’nın 2013 yılı itibariyle mal ihracatının \%97,7'sinin petrol ihracatından oluşması yani ihracatta petrole bağımlılık gösterilebilir.

Sonuçlar ülkemiz açısından değerlendirildiğinde ise, Türkiye’nin 22 ülke arasında 17. sırada yer aldığ gözlemlenmektedir. 7 göstergenin 6'sinda (IND, COST, DOC, HINC, GANDS ve MANUF) ilk 16 ülke arasinda yer alan Türkiye'nin siralamada bu kadar gerilerde kalmasının başlıca sebebi ise en önemli göster- ge olarak belirlenen HTECH göstergesinde 20. sirada yer almasıdır. Buna göre, ülkemizin ihracat performansının artmasında HTECH ürünlerinin ihracattaki payını artırmaya dönük politikalar uygulanması oldukça önem arz etmektedir.

Çalışmanın en önemli boyutlarından birisi göstergelerin önem derecelerine göre farklı ağırlıklara sahip olmasıdır. Eğer analiz tüm göstergelere eşit oranda ağırlık verilerek yapılsaydı, sonuç ağılılıklı duruma göre şu şekilde farklılıklar gösterecekti; (i) performansı en iyi iki ülke yer değiştirecek ve Malezya 1., Filipinler 2. olacaktı, (ii) Türkiye ve Şili ağırlıklı duruma göre 6 sıra daha yukarıda olacaktı, (iii) Rusya ağırlıklı duruma göre 11 sıra daha geride olacaktı (bu durum Rusyảnın nitelikli ihracat yaptığını göstermektedir) ve (iv) 3. s1radaki Çin ve son sıradaki Venezuelảnın sıralamadaki yerleri değişmeyecekti (Ek-2).

Literatürde 3-4 uzman sayısının sıklıkla yeterli görülmesine karşın sonraki çalışmalarda görüşlerine başvurulan uzman sayısının arttırılması daha uygun olabilecektir. Ancak ihracat ve dış ticaret konusunda yetkin uzmanlara ulaşmak da araştırmacılar için zor olabilmektedir.

Ayrıca söz konusu çalışmada kısıtlı bir döneme ait kısıtlı bir ülke grubu için analiz yapılmıştır. İlerideki çalışmalarda tek bir dönem yerine yıllar itibariyle analize dahil olan ülkelerin ihracat performansını ve performans dalgalanmalarını analiz edecek çalışmaların yapılmasının ilgili literatür için faydalı olacağı değerlendirilmektedir.

Daha sonra yapılacak çalışmalarda VIKOR, MOORA, GRA gibi diğer çok kriterli karar verme yöntemleri de performans analizi için kullanılıp sonuçlar karşılaştırılmasının faydalı olacağı düşünülmektedir.

\section{Kaynakça}

Al-Yousif, Y. K. (1999). On the Role Exports in the Economic Growth of Malaysia: A Multivariate Analysis. International Economic Journal, 13 (3), 67-75.

Awokuse, T. O. (2003). Is the Export-Led Growth Hypothesis Valid for Canada?. Canadian Journal of Economics/Revue Canadienne Déconomique, 36 (1), 126-136. 
Aydın, Ö. (2009). Bulanık AHP ile Ankara için Hastane Yer Seçimi. Dokuz Eylül Üniversitesi İktisadi ve İdari Bilimler Fakültesi Dergisi, 24 (2), 87-104.

Aydın, Ö., Öznehir, S., Akcalı, E. (2009). Ankara İçin Optimal Hastane Yeri Seçiminin Analitik Hiyerarşi Süreci ile Modellenmesi. Süleyman Demirel Üniversitesi İktisadi ve İdari Bilimler Fakültesi Dergisi, 14 (2), 69-86.

Ayhan, M. B. (2013). A Fuzzy AHP Approach for Supplier Selection Problem: A Case Study in a Gearmotor Company. International Journal of $\mathrm{Ma}$ naging Value and Supply Chains (IJMVSC), 4 (3), 11-23.

Bahmani-Oskooee, M., Alse, J. (1993). Export Growth and Economic Growth: An Application of Cointegration and Error-Correction Modeling. The Journal of Developing Areas, 27 (4), 535-542.

Bahmani-Oskooee, M., Niroomand, F. (1999). Openness and Economic Growth: An Empirical Investigation. Applied Economics Letters, 6 (9), 557-561.

Balassa, B. (1978). Exports and Economic Growth: Further Evidence. Journal of Development Economics, 5 (2), 181-189.

Balcerzak, A., Pietrzak, M. B. (2014). Are New EU Member States Improving Their Institutional Effectiveness for Global Knowledge-based Economy? TOPSIS Analysis for the Years 2000-2010 (No. 16/2014). Toruń, Poland: Institute of Economic Research.

Balcerzak, A., Pietrzak, M. B. (2015). Human Development and Quality of Institutions in Highly Developed Countries (No. 156/2015). Toruń, Poland: Institute of Economic Research.

Balcerzak, A., Pietrzak, M. B. (2016). Application of TOPSIS Method for Analysis of Sustainable Development in European Union Countries (No. 22/2016). Toruń, Poland: Institute of Economic Research.

Banihashemi, S. A., Rejaei, Z. (2015). Analysis of the Digital Divide in Asia-Islamic Countries: A TOPSIS Approach. Journal of Asian Scientific Research, 5 (4), 165-176.
Behzadiyan, M., Otaghsara, S. K., Yazdani, M., Ignatius, J. (2012). A State-of the-Art Survey of TOPSIS Applications. Expert Systems with Applications, 39 (17), 13051-13069.

Bellman, R. E., Zadeh, L. A. (1970). Decision-Making in a Fuzzy Environment. Management Science, iv (4), 141-164.

Buckley, J. J. (1985). Fuzzy Hierarchical Analysis. Fuzzy Sets Systems, 17 (1), 233-247.

Chang, D-Y. (1996). Applications of the Extent Analysis Method on Fuzzy AHP. European Journal of Operational Research, 95 (3), 649-655.

Chen, C-T. (2000). Extensions of the TOPSIS for Group Decision-Making Under Fuzzy Environment. Fuzzy Sets and Systems, 114 (1), 1-9.

Çakır, S., Perçin, S. (2013). AB Ülkeleri’nde Bütünleşik Entropi Ağırlık-TOPSIS Yöntemiyle Ar-Ge Performansının Ölçülmesi. Uludağ Üniversitesi İktisadi ve İdari Bilimler Fakültesi Dergisi, 32 (1), 77-95.

Demireli, E. (2010). TOPSIS Çok Kriterli Karar Verme Sistemi: Türkiyedeki Kamu Bankaları Üzerine Bir Uygulama. Girişimcilik ve Kalkınma Dergisi, 5 (1), 101-112.

Deng, H. (1999). Multicriteria Analysis with Fuzzy Pairwise Comparison. International Journal of Approximate Reasoning, 21 (3), 215-231.

Dinçer, S. E. (2011). Multi-Criteria Analysis of Economic Activity for European Union Member States and Candidate Countries: TOPSIS and WSA Applications. European Journal of Social Sciences, 21 (4), 563-572.

Doraisamii, A. (1996). Export Growth and Economic Growth: A Reexamination of Some Time-Series Evidence of The Malaysian Experience. The Journal of Developing Areas, 30 (2), 223-230.

Ekanayake, E. M. (1999). Exports and Economic Growth in Asian Developing Countries: Cointegration and Error-Correction Models. Journal of Economic Development, 24 (2), 43-56. 
Eyüboğlu, K. (2016). Comparison of Developing Countries' Macro Performances with AHP and TOPSIS Methods. Çankırı Karatekin Üniversitesi İİF Dergisi, 6 (1), 1-16.

Feder, G. (1983). On Exports and Economic Growth. Journal of Development Economics, 12 (1), 59-73.

Frankel, J. A., Romer, D. (1999). Does Trade Cause Growth?. American Economic Review, 89(3), 379399.

Genç, T., Masca, M. (2013). Topsis ve Promethee Yöntemleri ile Elde Edilen Üstünlük Sıralamalarının Bir Uygulama Üzerinden Karşılaştırılması. Afyon Kocatepe Üniversitesi İktisadi ve İdari Bilimler Fakültesi Dergisi, 15 (2), 539-567.

Henriques, I., Sadorsky, P. (1996). Export-Led Growth or Growth-Driven Exports? The Canadian Case. Canadian Journal of Economics, 29 (3), 540-555.

Huang, J-H., Peng, K-H. (2012). Fuzzy Rasch Model in TOPSIS: A New Approach for Generating Fuzzy Numbers to Assess the Competitiveness of the Tourism Industries in Asian Countries. Tourism $\mathrm{Ma}$ nagement, 33 (2), 456-465.

Jahanshahloo, G. R., Lotfi, F. H., Izadikhah, M. (2006). An Algorithmic Method to Extend TOPSIS for Decision-Making Problems with Interval Data. Applied Mathematics and Computation, 175 (2), 1375-1384.

Jia, J., Fan, Y., Guo, X. (2012). The Low Carbon Development (LCD) Levels' Evaluation of the World's 47 Countries (Areas) by Combining the FAHP with the TOPSIS Method. Expert Systems with Applications, 39 (7), 6628-6640.

Karaoğlan, S., Şahin, S. (2016). DEMATEL ve AHP Yöntemleri İle İşletmelerin Satın Alma Problemine Bütünleşik Bir Yaklaşım, DSLR Kamera Örneği. İşletme Araştırmaları Dergisi, 8 (2), 359-375.

Kavoussi, R. M. (1984). Export Expansion and Economic Growth: Further Empirical Evidence. Journal of Development Economics, 14 (1), 241-250.
Kaya, P., Cetin, E. I., Kuruüzüm, A. (2011). Çok Kriterli Karar Verme ile Avrupa Birligi ve Aday Ülkelerin Yasam Kalitesinin Analizi. Ekonometri ve İstatistik Dergisi, 13 (1), 80-94.

Kim, G., Park, C. S., Yoon, K. P. (1997). Identifying Investment Opportunities for Advanced Manufacturing Systems with Comparative-Integrated Performance Measurement. International Journal of Production Economics, 50 (1), 23-33.

Kristjanpoller, W. R., Olson, J. E. (2014). Economic Growth in Latin American Countries: Is It Based on Export-Led or Import-Led Growth?. Emerging Markets Finance and Trade, 50 (1), 6-20.

Kunst, R. M., Marin, D. (1989). On Exports and Productivity: a Causal Analysis. The Review of Economics and Statistics, 71 (4), 699-703.

Kwan, A. C., Kwok, B. (1995). Exogeneity and the export-led growth hypothesis: the case of China. Southern Economic Journal, 61 (4), 1158-1166.

Mangir, F., Erdogan, S. (2011).“Comparison of Economic Performance Among Six Countries in Global Financial Crisis: The Application of Fuzzy TOPSIS Method. Economics, Management and Financial Markets, 6 (2), 122-136.

Marin, D. (1992). Is The Export-Led Growth Hypothesis Valid for Industrialized Countries?. The Review of Economics and Statistics, 74 (4), 678-688.

Michaely, M. (1977). Exports and Growth: An Empirical Investigation. Journal of Development Economics, 4 (1), 49-53.

Önder, E., Taş, N. H. (2015). Economic Performance Evaluation of Fragile 5 Countries After the Great Recession of 2008-2009 Using Analytic Network Process and TOPSIS Methods. Journal of Applied Finance \& Banking, 5 (1), 1-17.

Özden, Ü. H. (2012). AB’ye Üye Ülkelerin ve Türkiye’nin Ekonomik Performanslarına Göre Vikor Yöntemi ile Siralanması. İstanbul Ticaret Üniversitesi Sosyal Bilimler Dergisi, 11 (21), 455468. 
Paul, A., Popovici, O. C., Calin, C. A. (2014). The Attractiveness of CEE Countries for FDI. A Public Policy Approach Using the TOPSIS Method. Transylvanian Review of Administrative Sciences, $42,156-181$.

Pietrzak, M. B., Balcerzak, A. (2016). Quality of Human Capital and Total Factor Productivity in New European Union Members States (No. 23/2016). Toruń, Poland: Institute of Economic Research.

Ram, R. (1987). Exports and Economic Growth in Developing Countries: Evidence from Time-Series and Cross-Section Data. Economic Development and Cultural Change, 36 (1), 51-72.

Saaty, T. L. (1977). A Scaling Method for Priorities in Hierarchical Structures. Journal of Mathematical Psychology, 15 (3), 234-281.

Saleem, A., Sial, M. H. (2015). Exports-Growth Nexus in Pakıstan: Cointegration and Causality Analysis. Pakistan Economic and Social Review, 53 (1), 17-46.

Samut, P. K. (2014). İki Aşamalı Çok Kriterli Karar Verme ile Performans Değerlendirmesi: AHP ve TOPSIS Yöntemlerinin Entegrasyonu. Anadolu Üniversitesi Sosyal Bilimler Dergisi, 14 (4), 57-67.

Sengupta, J. K., Espana, J. R. (1994). Exports and Economic Growth in Asian NICs: An Econometric Analysis for Korea. Applied Economics, 26 (1), 4151.

Shih, H-S., Shyur, H-J., Lee, E. S. (2007). An Extension of TOPSIS for Group Decision Making. Mathematical and Computer Modelling, 45 (7), 801-813.

Sofyalıoglu, Ç. (2009). Bulanık Analitik Hiyerarşi Süreci ile Uygun Altı Sigma Metodolojisinin Seçimi. Journal of Management \& Economics, 16 (2), 1-17.

Şimşek, M. (2003). İhracata Dayalı-Büyüme Hipotezinin Türkiye Ekonomisi Verileri ile Analie zi, 1960-2002. Dokuz Eylül Üniversitesi İktisadi ve İdari Bilimler Fakültesi Dergisi, 18 (2), 43-63.
Thornton, J. (1996). Cointegration, Causality and Export-Ld Growth in Mexico, 1895-1992. Economics Letters, 50 (3), 413-416.

Tsaur, S-H., Chang, T-Y., Yen, C-H. (2002). The Evaluation of Airline Service Quality by Fuzzy MCDM. Tourism Management, 23 (2), 107-115.

Tunca, M. Z., Ömürbek, N., Cömert, H. G., Aksoy, E. (2016). Opec Ülkelerinin Performanslarının Çok Kriterli Karar Verme Yöntemlerinden Entropi ve Maut ile Değerlendirilmesi. Visionary E-Journal/ Vizyoner Dergisi, 7 (14), 1-12.

Tyler, W. G. (1981). Growth and Export Expansion in Developing Countries: Some Empirical Evidence. Journal of Development Economics, 9 (1), 121-130.

Ustasüleyman, T. (2009). Bankacılık Sektöründe Hizmet Kalitesinin Değerlendirilmesi: Ahs-Topsis Yöntemi. Bankacılar Dergisi, 69, 33-43.

Vaidya, O. S., Kumar, S. (2006). Analytic Hierarchy Process: An Overview of Applications. European Journal of Operational Research, 169 (1), 1-29.

Van Laarhoven, P. J. M., Pedrycz, W. (1983). A Fuzzy Extension of Saaty's Priority Theory. Fuzzy Sets and Systems, 11 (1-3), 199-227.

Yılmaz, E. (2012). Bulanık AHP - VIKOR Bütünleşik Yöntemi ile Tedarikçi Seçimi. Marmara Üniversitesi İ.I.B.F. Dergisi, 33 (2), 331-351.

Zadeh, L. A. (1965). Fuzzy Sets. Information and Control, 8 (3), 338-353.

Zanakis, S. H., Solomon, A., Wishart, N., Dublish, S. (1998). Multi-Attribute Decision Making: A Simulation Comparison of Select Methods. European Journal of Operational Research, 107 (3), 507-529. 
Ek-1. Uzmanlara Ait İkili Karşılaştırmalar

\begin{tabular}{l|c|c|c|c|c|c|c}
\hline Uzman-I & IND & COST & DOC & HINC & GANDS & HTECH & MANUF \\
\hline IND & 1 & 9 & 9 & $1 / 5$ & 8 & $1 / 8$ & 8 \\
COST & $1 / 9$ & 1 & 7 & $1 / 9$ & $1 / 7$ & $1 / 9$ & $1 / 8$ \\
DOC & $1 / 9$ & $1 / 7$ & 1 & $1 / 8$ & $1 / 7$ & $1 / 9$ & $1 / 7$ \\
HINC & 5 & 9 & 8 & 1 & 9 & $1 / 4$ & 7 \\
GANDS & $1 / 8$ & 7 & 7 & $1 / 9$ & 1 & $1 / 9$ & 2 \\
HTECH & 8 & 9 & 9 & 4 & 9 & 1 & 8 \\
MANUF & $1 / 8$ & 8 & 7 & $1 / 7$ & $1 / 2$ & $1 / 8$ & 1 \\
\hline
\end{tabular}

\begin{tabular}{l|c|c|c|c|c|c|c}
\hline Uzman-II & IND & COST & DOC & HINC & GANDS & HTECH & MANUF \\
\hline IND & 1 & 3 & 7 & $1 / 5$ & 4 & $1 / 8$ & 4 \\
COST & $1 / 3$ & 1 & 5 & $1 / 6$ & $1 / 6$ & $1 / 8$ & $1 / 7$ \\
DOC & $1 / 7$ & $1 / 5$ & 1 & $1 / 7$ & $1 / 8$ & $1 / 9$ & $1 / 7$ \\
HINC & 5 & 6 & 7 & 1 & 9 & $1 / 7$ & 4 \\
GANDS & $1 / 4$ & 6 & 8 & $1 / 9$ & 1 & $1 / 7$ & $1 / 3$ \\
HTECH & 8 & 8 & 9 & 7 & 7 & 1 & 5 \\
MANUF & $1 / 4$ & 7 & 7 & $1 / 4$ & 3 & $1 / 5$ & 1 \\
\hline
\end{tabular}

\begin{tabular}{l|c|c|c|c|c|c|c}
\hline Uzman-III & IND & COST & DOC & HINC & GANDS & HTECH & MANUF \\
\hline IND & 1 & 5 & 3 & $1 / 5$ & $1 / 5$ & 7 & $1 / 5$ \\
COST & $1 / 5$ & 1 & 3 & $1 / 5$ & $1 / 5$ & $1 / 7$ & $1 / 5$ \\
DOC & $1 / 3$ & $1 / 3$ & 1 & $1 / 5$ & $1 / 5$ & $1 / 7$ & $1 / 5$ \\
HINC & 5 & 5 & 5 & 1 & 5 & $1 / 7$ & 1 \\
GANDS & 5 & 5 & 5 & $1 / 5$ & 1 & $1 / 7$ & $1 / 3$ \\
HTECH & $1 / 7$ & 7 & 7 & 7 & 7 & 1 & 5 \\
MANUF & 5 & 5 & 5 & 1 & 3 & $1 / 5$ & 1 \\
\hline
\end{tabular}

\begin{tabular}{l|c|c|c|c|c|c|c}
\hline Uzman-IV & IND & COST & DOC & HINC & GANDS & HTECH & MANUF \\
\hline IND & 1 & 6 & 7 & $1 / 4$ & 6 & $1 / 5$ & $1 / 5$ \\
COST & $1 / 6$ & 1 & 4 & $1 / 5$ & $1 / 6$ & $1 / 5$ & $1 / 5$ \\
DOC & $1 / 7$ & $1 / 4$ & 1 & $1 / 5$ & $1 / 5$ & $1 / 5$ & $1 / 6$ \\
HINC & 4 & 5 & 5 & 1 & 4 & $1 / 5$ & 4 \\
GANDS & $1 / 6$ & 6 & 5 & $1 / 4$ & 1 & $1 / 5$ & $1 / 6$ \\
HTECH & 5 & 5 & 5 & 5 & 5 & 1 & 6 \\
MANUF & 5 & 5 & 6 & $1 / 7$ & 6 & $1 / 6$ & 1 \\
\hline
\end{tabular}

Ek-2. Performans Kriterleri Ağırıklandırılmadan Yapılan Değerlendirme Sonuçları

\begin{tabular}{rlrrrr}
\hline SIra & Ülkeler & $S_{i}^{*}$ & $S_{i}^{-}$ & $C_{i}^{*}$ & Değisiim \\
\hline $\mathbf{1}$ & Malezya & 4,857 & 11,443 & 0,70203 & $\mathbf{1 \uparrow}$ \\
$\mathbf{2}$ & Filipinler & 6,690 & 10,977 & 0,62133 & $\mathbf{1}$ \\
$\mathbf{3}$ & Çin & 6,389 & 9,854 & 0,60664 & $\leftrightarrow$ \\
$\mathbf{4}$ & Macaristan & 6,510 & 9,522 & 0,59392 & $\mathbf{1 \uparrow}$ \\
$\mathbf{5}$ & Tayland & 6,472 & 8,973 & 0,58099 & $\mathbf{1}$ \\
$\mathbf{6}$ & Polonya & 7,958 & 8,031 & 0,50229 & $\mathbf{1 \uparrow}$ \\
$\mathbf{7}$ & Bulgaristan & 8,024 & 7,558 & 0,48503 & $\mathbf{3 \uparrow}$ \\
$\mathbf{8}$ & Meksika & 8,407 & 7,150 & 0,45963 & $\mathbf{2} \downarrow$ \\
$\mathbf{9}$ & Romanya & 8,655 & 7,187 & 0,45369 & $\mathbf{2 \uparrow}$ \\
$\mathbf{1 0}$ & Hindistan & 8,960 & 6,812 & 0,43192 & $\mathbf{2}$ \\
$\mathbf{1 1}$ & Türkiye & 9,833 & 6,987 & 0,41542 & $\mathbf{6 \uparrow}$ \\
$\mathbf{1 2}$ & Endonezya & 9,935 & 6,717 & 0,40339 & $\mathbf{4 \uparrow}$ \\
$\mathbf{1 3}$ & Peru & 10,227 & 6,418 & 0,38556 & $\mathbf{5 \uparrow}$ \\
$\mathbf{1 4}$ & Pakistan & 10,856 & 6,629 & 0,37912 & $\mathbf{5 \uparrow}$ \\
$\mathbf{1 5}$ & Şili & 10,208 & 5,855 & 0,36450 & $\mathbf{6 \uparrow}$ \\
$\mathbf{1 6}$ & Ukrayna & 9,554 & 5,308 & 0,35716 & $\mathbf{1} \downarrow$ \\
$\mathbf{1 7}$ & Güney Afrika & 10,139 & 5,024 & 0,33135 & $\mathbf{3 \uparrow}$ \\
$\mathbf{1 8}$ & Arjantin & 10,433 & 4,627 & 0,30723 & $\mathbf{5} \downarrow$ \\
$\mathbf{1 9}$ & Kolombiya & 10,748 & 4,293 & 0,28542 & $\mathbf{5} \downarrow$ \\
$\mathbf{2 0}$ & Rusya & 10,288 & 4,059 & 0,28291 & $\mathbf{1 1} \downarrow$ \\
$\mathbf{2 1}$ & Brezilya & 10,527 & 4,065 & 0,27859 & $\mathbf{9} \downarrow$ \\
$\mathbf{2 2}$ & Venezuela & 13,059 & 1,352 & 0,09379 & $\leftrightarrow$ \\
\hline
\end{tabular}

